\title{
RAZÃO E EMOÇÃO: \\ Uma questão de equilíbrio também no ato de julgar
}

Ana Maria Moreira de Sousa Mendes Bezerra

Aluna do Curso de Direito da FA7. Relato sob a orientação do prof. Me. Danilo Fontenele (FA7).

aninhabezerra_@hotmail.com

\section{INTRODUÇÃO}

O juiz, comumente, é representado, supersticiosamente, como uma figura apática, firme e racional. É deixado de lado, muitas vezes, o fato de ele ser humano, como qualquer outro, apesar de parecer óbvio, trazendo em si uma carga emocional que pode influenciá-lo e, consequentemente, as suas decisões, de maneira considerável. É representado, então, como um ser circunstancial e, portanto, imprevisível.

O presente relato pretende ser o ponto de partida para uma pesquisa mais profunda a respeito da importância da emoção no comportamento humano, em especial, no do juiz, e as consequências disso.

Essa influência proveniente da emoção, que, vale ressaltar, não alcança apenas o juiz, mas todo e qualquer indivíduo, abre um leque de possíveis discussões, que podem ir desde Freud e o papel do inconsciente na mente humana até as críticas de Damásio a Descartes em sua obra O Erro de Descartes (1996). Nesse contexto, o paradoxo Razão/Emoção se faz muito presente na introdução ao assunto, assim como a ideia de separação do método utilizado pelas ciências naturais do das ciências humanas, em especial, o Direito. Também, as teses epistemológicas merecem destaque na discussão em questão.

Partindo dessas abordagens pretendidas inicialmente, a pesquisa em questão propõe uma reflexão a respeito de como seria um juiz "ideal”, aquele que é verdadeiramente justo em suas decisões.

\section{Referencial Teórico}

No que tange às discussões introdutórias e essenciais ao assunto em questão, Damásio (1996), criticando o método cartesiano e o racionalismo de Descartes, permite que a discussão sobre emoção seja iniciada. É importante salientar, também, a superação do pensamento comteano de que as ciências humanas caminham no mesmo sentido que as ciências naturais, tornando improváveis a previsibilidade e a elaboração de leis causais e de certezas quando se trata de humanos. 
Nesse contexto, ainda, o Positivismo jurídico, que reflete as ideias iluministas do século XVIII, em que há uma crença exacerbada na razão, torna-se enfraquecido e não aplicável com sucesso às ciências humanas, inclusive ao Direito.

Depois de realizada uma breve análise histórica, lançar-se-á um olhar para o Juiz. Nesse sentido, todo e qualquer juiz deve ter, como objetivo, a justiça. Para isso, deve ser imparcial em uma primeira análise do caso concreto, sem se deixar influenciar por simpatias ou inimizades. Até que ponto, entretanto, o caso analisado não vai ter sua decisão comprometida por causa de pensamentos inconscientes, porém inevitáveis, de um determinado juiz? Nesse sentido, os ensinamentos de Freud sobre o inconsciente tornam-se muito importantes para a pesquisa.

Nota-se que não é possível atingir e controlar o inconsciente de um juiz, nem ele mesmo o consegue. O que se mostra possível prever, mesmo que de maneira não absoluta, é o potencial que uma pessoa tem para lidar com situações capazes de mexer com seus pensamentos e sentimentos, como em vários casos concretos analisados por um juiz, que deve manter um distanciamento crítico por mais impressionante que o caso seja para ele. Esse potencial deve ser analisado ainda na seleção para o cargo de juiz; é a análise de parte da Inteligência Emocional, muito discutida por Daniel Goleman (2012).

Faz-se necessária, então, uma avaliação que vá além da técnica formal, adentrando nos aspectos emocionais do indivíduo, quais sejam: como ele lida com pressões, ansiedades, medos e traumas. Assim, um indivíduo que saiba lidar com esses aspectos, normalmente porque apresenta, de certo modo, um autoconhecimento, seria um profissional mais adequado ao cargo de juiz, tendendo a conseguir ser imparcial, mesmo tendo seus preconceitos e ideais. Augusto Cury (2014, p. 19) reforça essa ideia ao defender que o "desenvolvimento de um Eu maduro, capaz de proteger a emoção, gerenciar pensamentos e trabalhar outras funções complexas da inteligência" é mais feliz em suas decisões e na própria vida, de maneira geral.

A autora Lídia Reis de Almeida Prado, em sua obra O Juiz e a Emoção - Aspectos da Lógica da Decisão Judicial (2005), contribui com esse tema de maneira extremamente relevante, aliando o Direito e a Psicologia, ao defender que a atual base da teoria do conhecimento é a interdisciplinaridade.

\section{Proposta de Sumário}

1. Queda do racionalismo exacerbado

\subsection{Ciências Humanas X Ciências Naturais}

1.2. Positivismo - do ápice ao enfraquecimento

2. A força da emoção

2.1. Daniel Goleman e a falha do QI

2.2. O poder influenciador do Inconsciente

3. Reflexos no ato de julgar

3.1. Distanciamento crítico e aproximação afetiva - O Equilíbrio

3.2. A Imparcialidade e o Justo - O ideal 


\section{Resultados Alcançados e/ou Esperados}

Lídia Prado relaciona a postura do juiz com o quadro de Salvador Dalí, em que uma mulher, com toda sua sensibilidade e leveza, abraça um livro grande, rígido e pesado; ela compara essa postura com a que o juiz deve seguir: no ato de julgar, é necessário que seja sensível e cuidadoso ao "abraçar" as leis postas. Desse modo, ele estaria se aproximando de uma decisão justa.

Essa ideia retrata o ponto central que a presente pesquisa destinou-se a estabelecer: é desejado que haja uma busca constante do equilíbrio entre razão e emoção, tanto na vida comum, como no ramo jurídico, mais especificamente no ato de julgar. Então, não se pode ignorar o fato de que o juiz, na vida real, não é - e nem deve ser - apenas racional. Daí a relevância de avaliar a inteligência emocional de um concursando que visa a esse cargo; deve-se avaliar além da capacidade técnica de saber leis e códigos, analisando, também, a sua capacidade de controle emocional e sua vontade de ser verdadeiramente justo.

\section{Considerações Finais}

Tendo como base, principalmente, as obras dos autores citados, essa pesquisa pretende ir muito mais adiante, de modo que, no futuro, as ideias aqui lançadas sejam analisadas de modo mais detalhado e aprofundado, da maneira que o tema permite e, até mesmo, exige.

\section{REFERÊNCIAS}

CURY, Augusto. Ansiedade: como enfrentar o mal do século: a Síndrome do Pensamento Acelerado: como e por que a humanidade adoeceu coletivamente, das crianças aos adultos. São Paulo: Saraiva, 2014.

DAMASIO, Antônio R. O erro de Descartes: emoção, razão e o cérebro humano. São Paulo: Companhia das Letras, 1996.

GOLEMAN, Daniel. Inteligência Emocional: a teoria revolucionária que redefine o que é ser inteligente. Rio de Janeiro: Objetiva, 2012.

PRADO, Lídia Reis de Almeida. O Juiz e a Emoção: aspectos da lógica judicial. 3. ed. Capinas, SP: Millenium, 2005. 
